Маланій Н. Аизакілиті в американському мітературному дискурсі ...

УДК 821.111(73)

DOI https://doi.org/10.24919/2308-4863/34-3-18

Назар МАЛАНІЙ,

orcid.org/0000-0002-9302-6212

кандидат філологічних наук,

докторант кафедри германських мов $і$ зарубіжної літератури

Кам'янеиь-Подільського начіонального університету імені Івана Огієнка (Кам'янеиь-Подільський, Хмельницька область, Україна) tg67@ukr.net

\title{
ДИЗАБІЛИТІ В АМЕРИКАНСЬКОМУ ЛІТЕРАТУРНОМУ ДИСКУРСІ ПЕРШОЇ ПОЛОВИНИ ХІХ СТОЛІТТЯ
}

\begin{abstract}
У статті порушено питання конструювання дизабілиті в літературному просторі Сполучених Штатів Америки першої половини ХІХ століття. Теоретичною основою розвідки є студії дизабілиті як однієї з наріжних частин досліджень ненормативної тілесності. Вона сформувалась на межі тисячоліть в окрему академічну дисиипліну в межах західної гуманітаристики, ї̈ представники фокусуються на особливостях сприйняття осіб із відмінною тілесністю як у сьогоденні, так і в минувшині. Сильною стороною методологічних напрацювань учених трансатлантичного англомовного простору є застосування широкого спектра міждисииплінарних підходів, запозичених із філософії, медицини, політологї, економічної теорії, соиіології тощяо.

Українські літературознавці мало вивчали проблему дизабілиті. Їхні спорадичні праці охоплюють здебільшого письменників сучасності. Отже, мета роботи - ие систематизація діахронічних зрізів ненормативної тілесності у творчості письменників пізнього американського романтизму ХІХ сторіччя. Провідним завданням статті є виявлення закономірностей у творенні системи образів і персонажів із дизабілиті у творах Натаніеля Готорна («Родимка») («The Birth-Mark», 1843) та Едтара Аллана По («Жабка») («Нор-frog», 1850).

Становлення дискурсу ненормативної тілесності на теренах Сполучених Штатів Америки відбувалося в складних геополітичних умовах. Попри зовнішні та внутрішні потрясіння, новоутвореній краӥні вдалась досягнути значних успіхів завдяки залученню найкращих учених та наукових здобутків Свропи. Винятком не стала $i$ література, яка, абсорбувавши тогочасні мистецько-філософські віяння, все ж спиралася на власні соціальнокультурні реалії. Обидва письменники намагались завдяки своїм доробкам розкрити ту систему упереджень $i$ труднощів, з якими стикалася людина з дизабілиті ХІХ століття. Їхня життєва мудрість помножена на неабиякий письменницький хист і заклала фундамент літературних студій ненормативної тілесності окресленого періоду.
\end{abstract}

Ключові слова: дизабілиті, ненормативна тілесність, Інше тіло, романтизм.

Nazar MALANII, orcid.org/0000-0002-9302-6212 Candidate of Philological Sciences,

Doctoral Candidate at the Department of Germanic Languages and Foreign Literature Kamianets-Podilskyi Ivan Ohiienko National University (Kamyanets-Podilsky, Khmelnytsky region, Ukraine)tg67@ukr.net

\section{DISABILITY IN THE AMERICAN LITERARY DISCOURSE OF THE FIRST HALF OF THE XIX CENTURY}

The article raises the issue of constructing disability in the literary space of the United States of America in the first half of the XIX century. The theoretical basis of the article is the study of disability as one of the cornerstones of research on non-normative corporeality. Formed at the turn of the millennium into a separate academic discipline within the Western humanities, their representatives focus on the peculiarities of the perception of people with Oher physicality both in the present and in the past. A strong point of the methodological developments of scientists of the transatlantic Englishspeaking space is the application of a wide range of interdisciplinary approaches borrowed from philosophy, medicine, political science, economic theory, sociology and more.

Ukrainian literary critics have studied little about the problem of disability. Their sporadic works cover mostly contemporary writers. Thus, the purpose of the work is to systematize diachronic sections of non-normative corporeality in the works of writers of late American romanticism of the XIX century. The main task of the article is to identify patterns in the creation of a system of images and characters with disability in the works of Nathaniel Hawthorne "Birthmark" (1843) and Edgar Allan Poe "Hop-frog" (1850).

The formation of the discourse of non-normative corporeality in the United States took place in a difficult geopolitical environment. However, despite external and internal shocks, the newly formed country has managed to achieve significant 
success by attracting the best scientists and scientific achievements of Europe. Literature was no exception, which, having absorbed the artistic and philosophical trends of the time, still relied on its own socio-cultural realities. Both writers tried to reveal the range of prejudices and difficulties faced by people with disability in the nineteenth century. Their wisdom of life was multiplied by a remarkable literary flair and laid the foundation of literary studies of the non-normative corporeality of the outlined period.

Key words: disability, non-normative corporeality, Other body, romanticism.

Постановка проблеми. Здобутки розвинених англомовних країн $\epsilon$ рушійною силою світової науки, зокрема гуманітарних дисциплін. До них належать студії дизабілиті, головні підвалини яких були закладені після закінчення Другої світової війни. Провідну роль в їх становленні відіграли й продовжують відігравати вчені з Великобританії та Сполучених Штатів Америки. Заглиблюючись у теперішні хитросплетіння ненормативної тілесності, вони не забувають і про минулі епохи. Ключовим у цьому сенсі $є$ саме XIX століття як переломний етап людської історії. Його світогляд і умонастрій стали каталізатором кривавих потрясінь уже першої половини XX сторіччя. Тому актуальною в українському контексті постає експлікація проблем осіб з Іншим тілом цього періоду в річищі загального становлення боротьби маргіналізованих меншин за свої права.

Аналіз досліджень. Україна сьогодення робить перші кроки до запозичення загальноєвропейської практики максимальної інклюзії осіб, відмінних фізично і психічно, у всі сфери життя суспільства. Питання генезису дизабілиті цікавили багатьох зарубіжних учених (Мішель Фуко, Сьюзен Зонтаг, Анрі-Жак Стікер, Леннард Дж. Девіс). Серед вітчизняних - це Ольга Бандровська (Бандровська, 2014), котра в межах дослідження антропологічних проєкцій торкалася побутування інвалідності в британському романі межі XIX - початку $\mathrm{XX}$ сторіч. У загальних обрисах сьогодення писали про тілесних Інших також Тамара Гундорова (Гундорова, 2012), Тетяна Свербілова (Свербілова, 2015), Вікторія Суковата (Суковата, 2012), Оксана Узлова (Узлова, 2015) та інші.

Мета статті. У зв'язку 3 поодиноким представленням питань дизабілиті на вітчизняних теренах ми визначаємо метою нашої розвідки узагальнення полівалентного характеру дизабілиті в американській літературі першої половини XIX століття. Для досягнення мети ставимо собі за завдання систематизувати структуру образів і персонажів із дизабілиті у творах Натаніеля Готорна («Родимка») та Едгара Аллана По («Жабка»).

Виклад основного матеріалу. Нині Сполучені Штати Америки є беззаперечним лідером демократичного світу, однак шлях до цього статусу був важким. У вирі запеклої революційної боротьби наприкінці XVIII сторіччя нова держава виборола незалежність від Британської імперії. Непросте XIX століття стало періодом становлення молодої країни, яке можна умовно розділити на два етапи. Перший тривав до Громадянської війни й ознаменувався територіальним розширенням, другий після її закінчення - масштабною реконструкцією та всеосяжною індустріалізацією. Попри ці складні вікопомні події, було закладено фундамент інституційного розв'язання проблеми дизабілиті, заснованої на підходах медичної моделі. У першій половині XIX сторіччя виникають перші школи для глухих та сліпих, притулки для психічно хворих, спеціалізовані товариства та неурядові організації із захисту їхніх прав. Проте саме кривавий міжусобний конфлікт 1861-1865 років, наслідком якого стали велика кількість скалічених фізично і ментально солдат, призвів до перегляду місця особи 3 дизабілиті в тогочасному суспільстві. Поряд із громадськими ініціативами формується державна політика в цьому злободенному питанні із визнанням необхідності пенсійного забезпечення, реабілітації та протезування воїнів. Відбувалося активне запозичення здобутків європейців Луї Брайля та Едуарда Сегена задля кращого навчання сліпих та розумово відсталих осіб. Поряд із цими звершеннями побутували сегрегаційне ставлення до дітей із дизабілиті афроамериканського походження та жахливі умови побуту в цих установах (Encyclopedia, 2009: XXIV - XXVIII). Підтвердженням цьому є праця «Суспільство в Америці» («Society in America») (1837) знаної британської письменниці та соціологині Гаррієт Мартіно (1802-1876). У своїх спостереженнях вона розкриває різні сторони американського життя початку XIX століття. Поряд 3 аналізом державного устрою, політики, економіки, іiі зацікавили найменш захищені та найбільш узалежнені верстви - діти, жінки й особи 3 відмінною тілесністю. Це недивно, адже сама авторка 3 юності мала погане здоров'я і страждала від значної втрати слуху. У кінцевому томі своєї розвідки у четвертому розділі під промовистою назвою «Страдники» («Sufferers»), який починається з епіграфа, взятого з книги «Обгрунтування релігійного дослідження» («The Rationale of Religious Inquiry») (1836) свого брата Джеймса Мартіно, стосовно природної рівності людей на основі християнської етики та важливості від- 
стоювання прав пригноблених особливо у час домінування одного класу над іншим, безсилля і забуті страждання осіб з дизабілиті предметно розглянуті ученою. Гаррієт Мартіно вказує на важливу відмінність США від переважно монархічного ландшафту континентальної Свропи наявність демократичного устрою. Завдяки його фундаментальним принципам справедливості та милосердя «в'язні, невігласи, нужденні та каліки врятовуються та благословляються» (Martineau, 1839: 180). Такий порятунок реалізується чисельними містами країни по-різному. 3 одного боку, це інституційно-медичне вирішення через будівництво притулків для божевільних, сліпих і глухих у Філадельфії, Бостоні, Нью-Йорку тощо, 3 іншого - це релігійно-благодійна модель через активну душпастирську діяльність кліру та меценатів. Попри їх лікування та навчання, дослідниця виокремила проблему відсутності регулярного працевлаштування для таких осіб. Проте ці підходи стосувалися здебільшого білого населення. Велике занепокоєння в письменниці викликало становище чорношкірих рабів із фізичними та психічними каліцтвами, отриманими під час важкої праці. Доля цих знедолених цілком залежала від милосердя своїх господарів. Безумних негрів почасти тримали у надвірних будівлях прикутими до стовпів, щоб запобігти їхній шкоді. Соціологиня, виокремивши позитивні й негативні сторони дизабілиті в Америці початку XIX століття, заохочує вчених вийти за межі панівної на той час філософії розуму і прагнути до нових горизонтів у розкритті природи ненормативної тілесності (Martineau, 1839: 190-199).

Зі становленням молодої держави формувалася й національна ідентичність, невіддільною частиною якої стала і література. Попри абсорбування творчих здобутків Великобританії та континентальної Європи, вона все ж розвивалася під панівним впливом американської суспільної та політичної культури. Ї̈̈ представники не могли залишити поза своєю увагою життя маргінальних груп індіанців як корінного народу, з одного боку, так афроамериканців, з іншого. Вони перенесли у свої книги палкі дискусії $з$ приводу необхідності скасування рабства, наслідків громадської війни, руху за соціальні реформи та напруженості між державою та людиною. Іноді їхні праці мали яскраво виражене провокативне забарвлення, метою якого було отримання необхідного резонансу соціуму. Одночасно із заснуванням основних установ, призначених для розміщення та навчання людей 3 обмеженими можливостями, митці були одержимі прогресивними ідеями того часу, покликаними до вдосконалення і розбудови сильнішого суспільства (Encyclopedia, 2009: 566-567).

Не менш разючою є історія дизабілиті в літературному дискурсі Америки вказаного періоду. Особливе значення для студій дизабілиті має доробок представників пізнього американського романтизму, а саме неперевершених Натаніеля Готорна та Едгара Аллана По. Творчість Натаніеля Готорна (1804-1864) сповнена глибинної символічності та алегоричності. Виключенням не $є$ його «Родимка» («The Birth-Mark», 1843). Ця новела $\epsilon$ яскравим прикладом дискусії в межах досліджень ненормативної тілесності з приводу дихотомічної діади норми/відхилення, яку детально описує Леннард Дж. Девіс (Disability Studies Reader, 2013). Він наголошує, що XIX століття у трансатлантичному дискурсі наповнене ідеями виправлення вад людської тілесності. Це стало можливим завдяки стрімкому науково-технічному прогресу періоду розквіту капіталізму, що викликало значне занепокоєння серед різних верств інтелігенції. Романтики вбачали у ньому велику загрозу самобутній природі людини. Вперше про це пише Мері Шеллі в романі «Франкенштейн; або сучасний Прометей» (1818). Наслідуючи запропонований нею мотив фаталістичного втручання, письменник робить головного персонажа Айлмера одержимим бажанням видалити вроджену родимку на лівій щоці своєї дружини Джорджіани. У творі автор представляє амбівалентність ставлення до людей $з$ особливими потребами того часу. Одні не вбачають у дефекті жодної проблеми, інші ж оповиті страхом і забобонами. Найближча людина також не приймає цієї маленької плямки, адже вона робить ії в очах чоловіка Іншою - неповноцінною та обтяженою особистістю, яка випадає iз загальноприйнятої соціальної системи. Будучи вченим-природознавцем, він ставить собі за мету будь-яким способом реалізувати задумане. Досягнувши цілі, чоловік відновлює досконалий образ своєї коханої, однак ціною іiі життя. Айлмер своїм вчинком відкинув найцінніше, що міг запропонувати йому світ. Ця фатальна родимка була єдиним знаком недосконалості людини, проте саме вона з'єднувала безсмертну душу із тлінною формою (Hawthorne, 1897: 51). Цей твір яскраво демонструє провідний тренд тієї доби, який зорієнтований на «покращення» тілесної форми індивіда. Адже по той бік Атлантичного океану на основі ідей британців Герберта Спенсера, Чарльза Дарвіна та Френсіса Гальтона він викристалізується в євгеніку, постулати якої стали виправданням антигуманних практик тоталітарних режимів вже XX століття. 
Поєднання відмінної тілесності 3 емоційною нестабільністю максимально проявлено також у культовому романі Натаніеля Готорна «Червона літера» («The Scarlet Letter», 1850), а саме в Роджері Чіллінгсворті. Подібно до Айлмера, він одержимий, але вже ревнощами. Метою його жалюгідного існування є помста. Автор використовує класичний прийом, коли зовнішня спотворена фізична форма виступає виразником темного внутрішнього простору. Подібно до Річарда III 3 однойменної п’єси Вільяма Шекспіра, художня постать антагоніста американського автора $\epsilon$ такою ж деформованою і скорченою, а причиною цьому є темні душевні поривання націлені на моральне пригнічення винного у його сімейній драмі молодого священника Дімсдейла.

Носії різноманітних тілесних вад завжди були об'єктом посиленої уваги, уїдливих насмішок та інтегральним елементом індустрії розваг. У XIX столітті особливою популярністю користувалися так звані фрік-шоу (freak shows), або шоу потвор, у тому числі із залученням людей із карликовістю. Недивно, що саме їх неперевершений Едгар Аллан По (1809-1849) зробить головними персонажами оповідання «Жабка» («Нор-frog»). Цей твір американських літературних студій дизабілиті є значущим і для нашої розвідки з огляду на представлену конотаційну різноманітність ненормативної тілесності. Його система образів має антиномічний характер. 3 одного боку, це здорова більшість - король і його сім міністрів, а 3 іншого - тілесно відмінна меншість, тобто насильно забрані із своїх домівок придворні карлики на прізвисько Жабка і його супутниця Тріпетта. В очах придворних вельмож блазень мав потрійну цінність, адже був «дурнем», карликом та калікою, що яскраво контрастувало 3 їхнім «ваговитим глуздом». Саме ці гладкі та опасисті незграби нарекли його Жабкою через конвульсивну ходу - не то вистрибом, не то вихилясом, що викликало нестримний регіт. Уже в самому описі головного героя казки автор показує класичні стереотипи до цієї групи людей з особливими потребами як у монархічній традиції, так і в тогочасному суспільстві США, а саме: розумову відсталість, психологічно-емоційну інфантильність та соціальну пасивність. У процесі оповіді Едгар По послідовно розвінчує ці упередження. Незважаючи на своє каліцтво, Жабеня має надзвичайно сильні м'язи рук, гострий, як на свій зріст, розум та надзвичайну сміливість. Саме завдяки цим якостям він вміло планує і реалізовує помсту своїм вульгарним кривдникам. Під час маскараду карлик переодягає вісім дворян у костюми орангутангів i, зв'язавши ланцюгами й підвісивши до стелі, спалює їх живцем. Ці трупи утворювали смердючу, обвуглену, огидну і розпливчату масу, яку можна розглядати як збірний образ репресивної політичної конструкції Америки XIX сторіччя (По, 1992). Жабка, подібно до інших бунтарів трансатлантичної традиції романтизму, кидає виклик цій усталеній соціально-політичній системі, сутність якої зводилася до стигматизації та приниження осіб із дизабілиті. У цьому контексті автор ламає звичне бачення проблеми завдяки розмиттю меж норми та відхилення. Перевтілення «здорових» вельмож у недоумкуватих тварин та ще й з обмеженою мобільністю демонструє читачеві ілюзорну нестабільність провідної тілесної ідентичності.

Персонажі 3 ненормативною тілесністю широко представлені в цілій низці різножанрових творів американської літератури XIX сторіччя: «Дім мого дитинства, який я бачу знову» (“Му Childhood Home I See Again", 1846) Авраама Лінкольна, «Мобі Дік, або Білий кит» ("Moby-Dick, or The Whale", 1851) Германа Мелвілла, «Життя на залізних млинах» (“Life in the Iron-Mills", 1861) Ребекки Хардінг Девіс, «Простаки за кордоном або Шлях нових паломників» (“The Innocents Abroad, or The New Pilgrims' Progress", 1869) Марка Твена, «Помилкова благодійність» (“A Mistaken Charity”, 1887) Мері Елеонор Вілкінс Фрімен, «Жінки та економіка» ("Women and Economics", 1898) і «Жовті шпалери» (“The Yellow Wallpaper”, 1899) Шарлотти Перкінс Гілмен, «Чудовисько» (“The Monster", 1899) Стівена Крейна. Цей перелік можна продовжити, однак саме ці праці становлять кістяк американського художнього бачення проблеми людей з особливими потребами, детальне вивчення яких спричинило б розширення і збагачення українських студій дизабілиті.

Висновки. Проаналізувавши твори Натаніеля Готорна та Едгара Аллана По, можна стверджувати, що завдяки строкатій системі образів і персонажів представлено полівалентний характер проблеми носіїв Іншого тіла 3 притаманним фаталізмом як інтегральною частиною світобачення пізнього романтизму. Різнить письменників кінцевий об'єкт неминучого кінця, у першому випадку - це безневинна і чиста жертва Джорджіана, в іншому, навпаки, - це зухвалі гнобителі Жабки. Попри цю відмінність, обидва твори розкривають основну тему соціально конструйованої напруги в діаді маргіналізованої меншості 3 дизабілиті та повноцінного суспільства завдяки 
палітрі нестійких дихотомій - здорового і хворого, потворного і прекрасного, комічного і трагічного чи розумного і дурного. Отже, ми конста- туємо важливість подальшого поступу в напрямі досліджень відмінної тілесності для української наукової думки.

\section{СПИСОК ВИКОРИСТАНИХ ДЖЕРЕЛ}

1. Бандровська О. Модернізм між минулим і майбутнім: антропологічний дискурс англійського роману. Львів : ЛНУ імені Івана Франка, 2014. 444 с.

2. Гундорова Т. Транзитна культура. Симптоми постколоніальної травми: есеї. Київ : Грані-Т, 2012. 548 с.

3. По Е. А. Жабка / український переклад А. В. Онишко, 1992. URL: http://ukrkniga.org.ua/ukrkniga-text/379/47/ (дата звернення 24.11.2020).

4. Свербілова Т. Мотив подорожі в сучасному синема-тексті в світлі соціальної моделі дизабілиті (ненормативної тілесності). Сучасні літературознавчі студії. 2015. Вип. 12. С. 488-505.

5. Суковата В. Теорія «дизабіліті» та конструкції інвалідності в масовій культурі. Соиіологія: теорія, методи, маркетинг. 2012. № 1. С. 84-98.

6. Узлова О. Хвороба як «наративний протез» (на матеріалі романів Девіда Лоджа «Терапія» і «Глухота як вирок»). Тіло як вистава: мистецькі проекиії : збірник наукових статей. Бердянськ : ФОП Ткачук О. В., 2015. С. 18-24.

7. Encyclopedia of American disability history / Edited by Susan Burch; foreword by Paul K. Longmore. New York : Infobase Publishing, 2009. $1106 \mathrm{p}$.

8. Hawthorne N. Little Masterpieces / Edited by Bliss Perry. New York : Doubleday \& McClure Co., 1897. 192 p.

9. Martineau, H. Society in America. In three volumes. Vol. III. Second Edition. London: Saunders and Otley, Conduit Street, $1839.365 \mathrm{p}$.

10. TheDisability StudiesReader/EditedbyLennardJ.Davis:FourthEdition.NewYorkandLondon:Routledge, 2013.578p.

\section{REFERENCES}

1. Bandrovska, O. (2014). Modernizm mizh mynulym i maibutnim: antropolohichnyi dyskurs anhliiskoho romanu [Modernism between the past and the future: the anthropological discourse of the English novel]. Lviv: LNU imeni Ivana Franka. [in Ukrainian].

2. Hundorova, T. (2012). Tranzytna kultura. Symptomy postkolonialnoi travmy: esei [Transit culture. Symptoms of Postcolonial Injury: Essays]. Kyiv.: Hrani-T. [in Ukrainian].

3. Poe E. A. Hop-Frog / ukrainskyi pereklad A. V. Onyshko, 1992. URL: http://ukrkniga.org.ua/ukrkniga-text/379/47/ (дата звернення 24.11.2020). [in Ukrainian].

4. Sverbilova, T. (2015). Motyv podorozhi v suchasnomu synema-teksti v svitli socialnoi modeli dyzabilyti (nenormatyvnoi tilesnosti) [The travel motive in modern cinema-text in light of social disability model (non-normative body)]. Suchasni literaturoznavchi studii. Vyp. 12. [in Ukrainian].

5. Sukovata, V. (2012). Teoriia "dyzabiliti" ta konstrukcii invalidnosti v masovii kulturi [The theory of "disability" and the designs of invalidity in mass culture]. Sociolohiia: teoriia, metody, marketynh. № 1. [in Ukrainian].

6. Uzlova, O. (2015). Khvoroba yak "naratyvnyi protez" (na materiali romaniv Devida Lodzha "Terapiia" i "Hlukhota yak vyrok") [Illness as a "narrative prosthesis" (based on the novels of David Lodge "Therapy" and "Deaf Sentence"]. Tilo yak vystava: mystetski proektsii: [zbirnyk naukovykh statei]. Berdiansk: FOP Tkachuk O. V. [in Ukrainian].

7. Encyclopedia of American disability history / Edited by Susan Burch; foreword by Paul K. Longmore. New York: Infobase Publishing, 2009. 1106 p. [in English].

8. Hawthorne N. Little Masterpieces / Edited by Bliss Perry. New York: Doubleday \& McClure Co., 1897. 192 p. [in English].

9. Martineau, H. Society in America. In three volumes. Vol. III. Second Edition. London: Saunders and Otley, Conduit Street, $1839.365 \mathrm{p}$.

10. The Disability Studies Reader (2013) / Edited by Lennard J. Davis : Fourth Edition. New York and London: Routledge. [in English]. 